October 05-08, 2020). Tokyo: ISG, 2020. P. 239-241. DOI 10.46299/ISG.2020.II.III

6. Zamsha A. Some aspects of bimodal-bilingual teaching children with hearing impairments. Pedagogy in the EU countries and in Ukraine at the present stage: International scientific and practical conference (Baia Mare, Romania, December 21 - 22, 2018). Baia Mare : Izdevnieciba «Baltija Publishing», 2018. C. 56-58.

DOI https://doi.org/10.30525/978-9934-26-146-6-9

\title{
КОМПЛЕКСНИЙ ПІДХІД ДО ДІАГНОСТИКИ ДІТЕЙ РАННЬОГО ВІКУ $З$ ООП
}

\author{
Реброва О. О. \\ аспірант \\ Інститут спеціальної педагогіки та психології \\ імені Миколи Ярмаченка \\ Національної академії педагогічних наук Украӥни \\ м. Київ, Украӥна
}

Досвід ранньої допомоги дітям заснований на багаторічних дослідженнях, які доводять, що грамотна організована рання корекційна робота здатна попередити появу вторинних відхилень у розвитку, забезпечити максимальну реалізацію реабілітаційного потенціалу, а для значної частини відкриває можливість включення їх в освітній потік.

Обов'язковим елементом ранньої допомоги $є$ діагностика розвитку дитини. В даний час існують кілька підходів до діагностики розвитку дітей раннього віку як в західній, так і у вітчизняній науці. Однак основним i загальним критерієм в діагностиці залишається комплексність і глибина.

Застосовуваний комплексний підхід до діагностики, повинен включати клінічні, параклінічні, психологічні та педагогічні дослідження. Клінічне дослідження дитини проводиться традиційними клінічними методами. Аналізуються скарги на стан здоров'я, поведінку дитини, вивчаються анамнестичні дані, проводиться огляд 3 аналізом соматовегетативних i неврологічних симптомів, оцінюється психоневрологічний статус.

Дані клінічного обстеження доповнюються даними параклінічних досліджень, що дозволяє скласти точніше уявлення про стан 36 
морфофункціональних структур мозку (ЕЕГ, ЕХО-ЕГ, РЕГ). При необхідності проводяться також дослідження стану зору та слуху. Електроенцефалографічне (ЕЕГ) дослідження - реєстрація біопотенціалів головного мозку, що дозволяє оцінити функціональний стан мозку, виявити локальні ураження різних відділів мозку, визначити характер цих поразок i наявність судомної готовності. Реоенцефалографіческое дослідження (РЕГ) - електрофізіологічне дослідження стану кровообігу судин головного мозку, що показує стан тонусу судинної системи мозку (артеріального кровообігу і венозного відтоку) [2].

Ехоенцефалографія (ЕхоЕГ) - ультразвукове дослідження стану ликвородинамики головного мозку, що дозволяс судити про наявність чи відсутність внутрішньочерепної гіпертензії. Дослідження можливо 3 перших днів життя дитини. Аудіологічні дослідження проводяться 3 перших місяців життя дитини із застосуванням: ігровий тональної порогової аудіометрії по умовно-рефлекторної методикою реєстрації слухових викликаних потенціалів (КСВП і ДСВП); педагогічне обстеження слуху: реєстрація відчуттів дитиною звучання мови і іграшок, сприйняття на слух мови; уточнення стану слуху і рівня загального i мовного розвитку в процесі педагогічних корекційних занять.

Офтальмологічні дослідження проводяться як традиційними методами, так і за допомогою розробленого в Інституті корекційної педагогіки РАО об'єктивного методу реєстрації зорових викликаних потенціалів (ЗВП), що дозволяє діагностувати порушення зору з перших днів життя дитини, оцінити ступінь цих порушень і простежити динаміку зорових функцій в процесі лікувально корекційних заходів.

Рефлексотерапія, яка займає особливе місце в роботі, $є$ самостійною сферою медицини і являє собою діагностичну і лікувальну систему. Основною особливістю рефлексотерапії $є$ можливість виявлення захворювання на ранній стадії, мобілізація власних ресурсів організму, відсутність алергічних реакцій, медикаментозної залежності, побічних впливів на організм, що має вирішальне значення при лікуванні дітей 3 відхиленнями у розвитку методами рефлексотерапії: голковколюванням, «припіканням», за допомогою масажу, КВЧ-терапії, кольоротерапії, лазерної та електропунктури. Психологічне дослідження дозволяє виявити рівень психічного розвитку дитини, особливості та динаміку розвитку, відповідність його психологічного і паспортного віку. Досліджуються: пізнавальна, ігрова, навчальна, творча, комунікативна діяльність; цілеспрямованість, працездатність, здатність до співпраці, здатність до навчання; увагу, пам'ять, здатність до вирішення простих і складних завдань, розуміння текстів; самооцінка, 
рівень домагань, переживання, і т. п. -все те, що дозволяє визначити психологічний вік дитини, «зону його найближчого розвитку», психологічні причини труднощів і порушень у розвитку. -психологічне дослідження включає спостереження, оцінку, застосовуються Листи оцінки дитячої поведінки (Child Behavior Checklist; CBCL) для обстеження дітей 3 відставанням в соціальній сфері або дітей 3 соціальноемоційними і поведінковими проблемами.

Нейропсихологічне обстеження дозволяє виявити порушення вищих коркових функцій i на цій основі більш обгрунтовано будувати індивідуалізовану програму корекційного навчання дитини. Методи діагностики порушень ВПФ різноманітні. Існують різні діагностичні системи. Найбільш використовується система нейропсихологічної діагностики яка була створена А. Р. Лурія. Процедура ії трудомістка та потребує подальшого системного аналізу виявленої симптоматики, іiі диференціації на первинну та вторинну [3].

Педагогічне обстеження - направлено на оцінку ступеня готовності до навчання за тією чи іншою програмою, рівня розвитку уявлень про навколишню дійсність, досягнень в освоєнні навчальних програм, сформованості елементарних шкільних навичок, виявлення прогалин в освоєнні навчальних предметів.

Логопедичні обстеження дозволяє виявити наявні у дитини порушення мови i визначити шляхи їх корекції. - логопедичне дослідження включає в себе визначення мовного анамнезу; оцінку експресивного мови; розуміння мови; оцінка різних видів мовної комунікації. Крім логопедичних методів обстеження мовлення застосовуються Тест розуміння слів, Лист оцінки жестів 3 CDIMакартура, Шкалу KID і Шкалу CDI.

Після чого різні фахівці мають можливість спираючись на висновки суміжних фахівців, зробити свої висновки про ідентифікацію проблемних областей, а також для опису сильних сторін розвитку дитини і вибір якісного маршруту реабілітації. Висновок, що має надатися батькам, грунтується на результатах всіх проведених досліджень і визначається комісією фахівців і носить рекомендаційний характер.

\section{Література:}

1. Архипова Е.Ф. Актуальні проблеми ранньої діагностики та корекції відхилень у розвитку // Спец. психологія. № 1 (3). - 2005. - С. 60.

2. Бадалян Л.О., Журба Л.Т., Всеволожская Н.М. Керівництво по неврології раннього дитячого віку. - Київ: Здоров'я, 1980. 
3. Візель Т.Г. Основи нейропсихології. Підручник для студентів. М.:В. Секачев, 2018. 264 с.

4. Джонсон-Мартін Н.М., Дженс К.Г., Аттерміер С.М., Хаккер Б.Дж. Програма «Кароліна» для немовлят і дітей молодшого віку з особливими потрібності / під. Ред. Н.Ю. Баранової. - СПб .: СанктПетербурзький Інститут раннього втручання, КАРО, 2005.

5. Корекційна допомога дітям раннього віку 3 органічним враженням центральної нервової системи в групах короткочасного перебування: метод. пособіе / під ред. Е.А. Стребелевой. - М., 2003. 